\title{
Hispanic Laborer Killed When Struck By Falling Plywood on a Commercial Construction Site
}

\author{
Incident Number: 14KY008
}

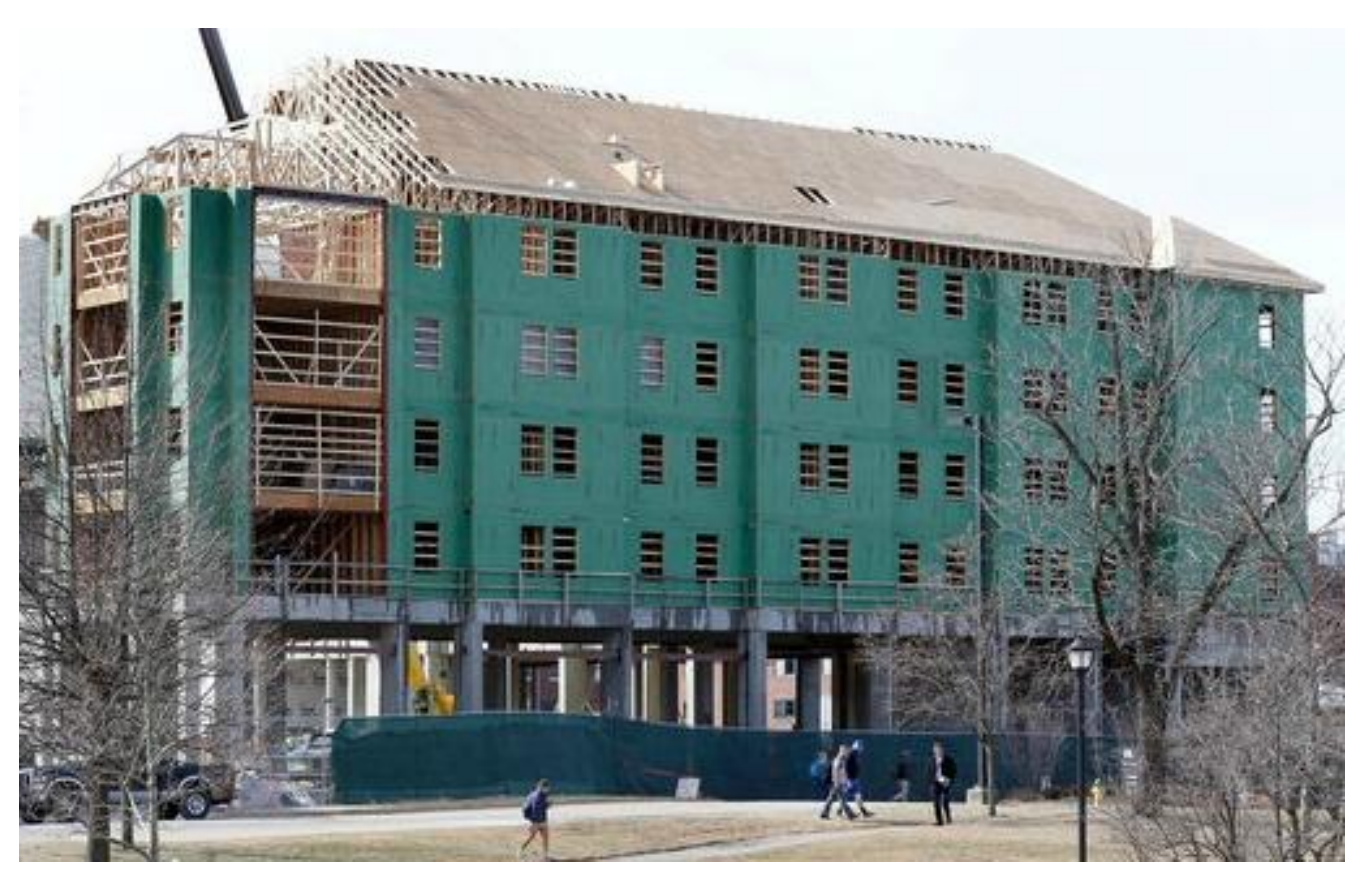

Kentucky Fatality Assessment and Control Evaluation Program Kentucky Injury Prevention and Research Center 333 Waller Avenue

Suite 242

Lexington, Kentucky 40504

Phone: 859-323-2981

Fax: 859-257-3909

www.kiprc.uky.edu

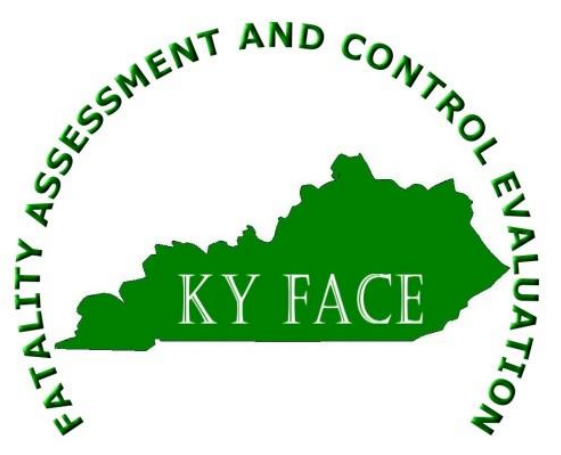




\title{
Kentucky Fatality Assessment and Control Evaluation (FACE) Program Incident Number: 14KY008 \\ Release Date: April 25, 2014 \\ Subject: Hispanic Laborer Killed when Struck by Falling Plywood on a Commercial Construction Site
}

\begin{abstract}
Summary
On a clear windy Wednesday, around 11:50 a.m., a 24 year-old Hispanic laborer was helping his brother-in-law load trusses on the ground, when a gust of wind ripped an 8 foot by 4 foot sheet of plywood from another Hispanic laborer's hands as he was handing the plywood to a co-worker 60 feet above on a commercial construction site roof. The co-worker on the roof tried to grab the sliding plywood by jumping onto it, but could not stop it. The co-worker's life line prevented him from falling over the edge of the roof. As the plywood reached the edge of the roof the wind whipped it 30 feet from the building, striking the Hispanic laborer on the back of the head just below his hard hat. A crane operator witnessing the events unfolding immediately began blowing his horn trying to warn the laborers on the ground, but it was too late.
\end{abstract}

To prevent future occurrences of similar incidents, the following recommendations have been made:

Recommendation No. 1: When conducting overhead work, employers should take precautions to protect workers on the ground from falling objects, tools and debris.

Recommendation No. 2: When possible, employers should move workers out of the hazard area when conducting overhead work.

Recommendation No. 3: When employers hire foreign workers, they should have training materials printed in the native language and provide extensive safety training to ensure understanding.

Recommendation No. 4: When the presence of high winds occurs, employers should consider postponing high overhead work to eliminate many incidents that could occur.

\section{Background}

The 24 year-old Hispanic laborer was born in Chiapas, Mexico. He had an elementary educational background and had been in the United States for 8 years. He had been a laborer in construction for two years and had hired on with his current company 5 months ago. He was the father of three daughters and resided in North Carolina. Friends and co-workers described him as a dedicated family man and a hard worker that would be dearly missed.

On the day of the fatal incident, the temperature was 55 degrees Fahrenheit with sunny, windy skies. At the time of the incident a wind gust was recorded at 26.5 M.P.H. at 11:54 a.m.. 


\section{Investigation}

The Kentucky Fatality Assessment and Control Evaluation Program was notified of an Occupational incident involving a Hispanic laborer by the local newspaper. The newspaper reported the laborer had been taken to the hospital, unconscious but in critical condition. The Kentucky Fatality Assessment and Control Evaluation Program was notified by Kentucky Occupational Safety and Health the next afternoon that the laborer had died at 4:48 p.m. in the local hospital's I.C.U. The laborer never regained consciousness.

On a clear, windy Wednesday morning around 11:50 a.m., a 24 year old Hispanic laborer was helping his brother-in-law load trusses on the ground. 60 feet above them, coworkers were nailing $8 \mathrm{ft}$. by $4 \mathrm{ft}$. plywood to the roof of a newly constructed commercial construction project. The coworkers on the roof stated they only had one more sheet of plywood to nail down and they would be finished with this side of the building. As one worker on the roof moved to hand off the last piece of plywood to a second worker, a gust of wind ripped the plywood from the first worker's hands and it started to slide down the roof. The first worker stated in a panic he tried to jump on the plywood to catch it but his yo-yo retractable fall protection lanyard of 6 feet grasped him and stopped his slide, allowing the plywood to continue off the roof. The wind caught the plywood as it slid towards the edge of roof and flung it 30 feet from the building where the laborer and his brother in law were loading the trusses. The crane operator witnessing the tragic situation unfold desperately blew his horn trying to warn the workers below. However, it was too late. The plywood struck the back of the laborer's head just below his protective hard hat knocking him to the ground. Co-workers rushed to aid him. A product delivery man was on site making a delivery and witnessed the incident. The delivery man immediately began CPR on the laborer until paramedics arrived within 4 minutes of the call to the 911 dispatcher.

The Hispanic laborer had been employed with this particular sub-contractor for 5 months but had worked construction in his home state of North Carolina. Prior to coming to this particular jobsite, the general contractor required that all sub-contractors and their employees hold a minimum certification of a 10 hour OSHA card to be allowed to perform work on the jobsite. The general contractor would then make copies and verify all 10 hour cards prior to orientation held by the general contractor before sub-contractors could begin working. The subcontractor's employees that were interviewed stated they all had a 10 hour OSHA class provided by the subcontractor prior to arriving on the job site. The 10 hour OSHA class was provided in English but there was a Spanish interpreter to ensure the Hispanic workers understood the material being taught in the classroom. However, the classroom material was not provided in Spanish, only English.

The general contractor stated after verifying all of the 10 hour OSHA cards, they conducted an orientation with the sub-contractors and employees that was site specific for the work they would be doing. The Orientation was 45 minutes to an hour and they went over the following programs. The fatal four, PPE, safety foresight program, tobacco free area, and hazard awareness and EPA and OSHA guidelines. The general contractor stated most of their requirements were stricter than OSHA but never less than what OSHA required. The general contractor also stated they left room to make certain safety changes as the work was inspected several times a day for safety hazards. 
The sub-contractor's foreman was interviewed regarding the incident. The foreman stated he was working on another job site in the area when the incident occurred, but came to the job site afterwards to take over. The foreman stated he had been in the construction business for 25 years and had been with this particular sub-contractor for the last two years, but had known the sub-contractor for longer. The foreman stated he had a 30 hour OSHA certification card but did not realize they expire, so he attended the 10 hour class the subcontractor provided prior to reporting to the job-site. The foreman was asked how the sub-contractor recruited his employees since they seemed to be from all over the nation. The foreman responded by saying it was usually word of mouth or if you showed up on a job site needing work. When asked what type of training the employees receive when hired, the foreman said they had to hold a 10 hour certification OSHA card and they were shown the policy book. When asked if the policy book was in Spanish, the foreman stated no. There was no other formal safety training provided to the employees. The foreman stated when they arrived on the job site, the general contractor required everyone to attend orientation and present their 10 hour OSHA certification cards. The foreman stated the general contractor went over safety issues with the employees prior to starting work.

The general contractor's safety manager spoke with the investigator. He validated they held orientation and described the information covered with the employees prior to starting the project. He stated his company does require all employees to carry a current OSHA 10 hour certification card. He also said during orientation, they covered the fatal four, requirements by the company, and requirements by the customer, as well as EPA and OSHA requirements. The safety manager said they went over PPE, the Foresight Program, Hazard Awareness, Emergency evacuation and where to go, and over-all awareness of your surroundings in general. The safety manager said his company's rules and policies were mostly stricter than OSHA required, but never less than OSHA regulations.

The safety manager explained they had a computerized system where they could plug in certain human behaviors they observed on each sub-contractor's employees and this system would then give the subcontractors a safety score. Any safety score $86 \%$ or below was considered unacceptable. This program helped the general contractor identify high risk contractors. When a subcontractor got a low score, their primary person responsible for employees was called into the general contractor's trailer and they would meet and go over the score and what they observed that needed improvement. The subcontractor would have to put together a written plan showing how they would take steps to correct this deficiency. The safety manager said the week before the incident, the subcontractor's owner was called in and they had a meeting with him over some of the observations they felt needed addressed.

The safety manager said the day before the incident, danger tape was used in the area to alert those in the area there is a hazard. On the day of the incident, there was no danger tape in the area where laborers where working on the ground. The safety manager also stated that toe boards were being used on the back side of the building, but not where the plywood was being installed. He did not know the reason for not using the toe boards. Toe boards could have prevented the plywood from slipping off the roof by acting as a stoppage for it at the edge of the roofline. 
The laborers interviewed stated about 20 minutes prior to the incident, their safety person came around and cautioned them of the hazard of the high wind. However, he did not address the situation and take preventable measures to caution off the area and control it. It was also found in a report the safety person wrote that he recognized the wind hazard yet he did not take any steps to prevent the hazard.

\section{Cause of Death}

The cause of death was blunt force trauma to the head caused by falling plywood.

Recommendation No. 1: When conducting overhead work, employers should take precautions to protect workers on the ground from falling objects, tools and debris.

In addition to wearing PPE, each employee shall be provided with additional protection from falling hand tools, debris and other small objects by installing toe-boards, screens, or guardrail systems, or through the erection of debris nets, catch platforms, or canopy structures that contain or deflect the falling object.

Recommendation No. 2: When possible, employers should move workers out of the hazard area when conducting overhead work.

The area below overhead work to which objects can fall shall be barricaded and employees shall not be permitted to enter the hazard area. This eliminates the possibility of falling tools, debris and other objects and striking workers below.

Recommendation No. 3: When employers hire foreign workers, they should have training materials printed in the native language and provide extensive safety training to ensure understanding.

Employers need to give their foreign workers extensive safety training. Many cultures are not focused on safety and therefore it's not always their first priority. Foreign workers are known for their productivity while safety takes a back seat. By extending safety training to these workers, it brings safety awareness to the front of everything they do. Providing training materials in their native language allows them to review what they have learned as well as eliminates the possibility of misunderstanding an interpretation.

\section{Recommendation No. 4: When the presence of high winds occur, employers should} consider postponing high overhead work to eliminate many incidents that could occur

The weather was a major contributor to the fatal incident since wind gusts at the time of the incident were $26.5 \mathrm{mph}$. and the workers were 60 feet in the air. Employers should never allow their roofers to get on the roof during windy situations or wet or iced areas, due to possible slips, falls and objects being blown off the roof area. Employers should adapt the OSHA standards for 
scaffolding use, 1926.451 (f) (12), that states work on or from scaffolds is prohibited during storms, or high winds unless a competent person has determined that it is safe for employees to be on the scaffold and those employees are protected by a personal fall arrest system or wind screens. Wind screens shall not be used unless the scaffold is secure against the anticipated wind forces imposed. This same standard should be applied to roofers as well.

\section{Keywords}

Construction

Roofing

Falling objects

High winds

\section{References}

http://www.Osha.gov

https://www.osha.gov/pls/oshaweb/owadisp.show_document?p_table=STANDARDS\&p_id=107 $\underline{52} 1926.451(\mathrm{~h})(1)$

https://www.osha.gov/pls/oshaweb/owadisp.show_document?p_table=STANDARDS\&p_id=107 $\underline{52} 1926.451(\mathrm{~h})(2)$

\section{Acknowledgements}

The Kentucky FACE program would like to thank the general contractor, the sub-contractor and their employees, as well as KYOSH investigator Renato Barrato for their assistance with this report.

\section{The Kentucky Fatality Assessment \& Control Evaluation Program (FACE) is funded by} grant 2U600H008483-09 from the Centers for Disease Control and Prevention and the National Institute for Occupational Safety and Health. The purpose of FACE is to aid in the research and prevention of occupational fatalities by evaluating events leading to, during, and after a work related fatality. Recommendations are made to help employers and employees have a safer work environment. For more information about FACE and KIPRC, please visit our website: www.kiprc.uky.edu 
